\title{
Hypocretins (Orexins) Regulate Serotonin Neurons in the Dorsal Raphe Nucleus by Excitatory Direct and Inhibitory Indirect Actions
}

\author{
Rong-Jian Liu, ${ }^{1}$ Anthony N. van den Pol, ${ }^{3}$ and George K. Aghajanian ${ }^{1,2}$ \\ Departments of ${ }^{1}$ Psychiatry, ${ }^{2}$ Pharmacology, and ${ }^{3}$ Neurosurgery, Yale School of Medicine, New Haven, \\ Connecticut 06508
}

The hypocretins (hcrt1 and hcrt2) are expressed by a discrete population of hypothalamic neurons projecting to many regions of the CNS, including the dorsal raphe nucleus (DRN), where serotonin (5-HT) neurons are concentrated. In this study, we investigated responses to hcrts in 216 physiologically identified 5-HT and non-5-HT neurons of the DRN using intracellular and whole-cell recording in rat brain slices. Hcrt1 and hcrt2 induced similar amplitude and dose-dependent inward currents in most $5-\mathrm{HT}$ neurons tested $\left(\mathrm{EC}_{50}, \sim 250 \mathrm{nM}\right)$. This inward current was not blocked by the fast $\mathrm{Na}^{+}$channel blocker TTX or in a $\mathrm{Ca}^{2+}$-free solution, indicating a direct postsynaptic action. The hcrt-induced inward current reversed near $-18 \mathrm{mV}$ and was primarily dependent on external $\mathrm{Na}^{+}$but not on external or internal $\mathrm{Ca}^{2+}$, features typical of $\mathrm{Na}^{+} / \mathrm{K}^{+}$nonselective cation channels. At higher concentrations, hcrts also increased spon- taneous postsynaptic currents in 5-HT neurons $\left(\mathrm{EC}_{50}, \sim 450-\right.$ $600 \mathrm{~nm}$ ), which were TTX-sensitive and mostly blocked by the $\mathrm{GABA}_{\mathrm{A}}$ antagonist bicuculline, indicating increased impulse flow in local GABA interneurons. Accordingly, hcrts were found to increase the basal firing of presumptive GABA interneurons. Immunolabeling showed that hert fibers projected to both 5-HT and GABA neurons in the DRN. We conclude that horts act directly to excite 5-HT neurons primarily via a TTX-insensitive, $\mathrm{Na}^{+} / \mathrm{K}^{+}$nonselective cation current, and indirectly to activate local inhibitory GABA inputs to 5-HT cells. The greater potency of hcrts in direct excitation compared with indirect inhibition suggests a negative feedback function for the latter at higher levels of hort activity.

Key words: hypocretin; serotonin; raphe; GABA; IPSC; sleep
The hypocretins (hcrt1 and hort2; also called orexin-A and orexin-B) are homologous neuropeptides synthesized by a discrete population of hypothalamic neurons (de Lecea et al., 1998; Sakurai et al., 1998). Hcrts have been implicated in many functions, including feeding, energy homeostasis, neuroendocrine functions, and cardiovascular control (Sakurai et al., 1998; van den Pol. et al., 1998; Samson et al., 1999). These two peptides activate with differing potencies two distinct Gq-coupled receptors, hcrtR1 and hcrtR2 (Sakurai et al., 1998). Loss of hcrt appears to be the primary cause of narcolepsy, a disease characterized by excessive daytime sleepiness and slow arousal, unusual REM (rapid eye movement) sleep patterns, cataplexy, and hypnogogic hallucinations (Lin et al., 1999; Peyron et al., 2000; Thannickal et al., 2000). Immunohistochemical studies show that hcrt neurons project to multiple brain regions that are implicated in the sleep-wake cycle, including serotonergic (5-HT) neurons of the raphe nucleus (DRN) (Peyron et al., 1998; Chemelli et al., 1999).

The involvement of 5-HT in the sleep-wake cycle has been studied for many years (Jouvet, 1999). Recent voltammetric and microdialysis experiments provide evidence that the release of 5-HT is highest during the waking state in most cortical and subcortical areas receiving serotonergic projections (Houdouin et al., 1991; Portas and McCarley, 1994; Portas et al., 1998, 2000).

Received April 17, 2002; revised June 24, 2002; accepted June 28, 2002.

This work was supported by National Institutes of Health Grants MH17871, NS41454, and NS37788 and by grants from the State of Connecticut. We thank Nancy Margiotta and Yang Yang, who provided excellent technical assistance.

Correspondence should be addressed to Rong-Jian Liu, Yale School of Medicine/ Connecticut Mental Health Center, 34 Park Street, New Haven, CT 06508. E-mail: rongjianl@hotmail.com.

Copyright $\odot 2002$ Society for Neuroscience $0270-6474 / 02 / 229453-12 \$ 15.00 / 0$
These data are consistent with the pattern of discharge of 5-HT neurons, with the highest firing rate occurring during alert waking, a decrease in slow-wave sleep, and virtual electrical silence during REM sleep (McGinty and Harper, 1976; Puizillout et al., 1979; Trulson and Jacobs, 1979; Cespuglio et al., 1981; Lydic et al., 1987). However, despite considerable evidence that both 5-HT and hort are involved in the sleep-wake cycle, relatively little attention has focused on interactions between these two systems.

The DRN contains the largest aggregate of 5-HT containing cells in the CNS (Dahlstrom and Fuxe, 1964). As mentioned above, 5-HT neurons in the DRN receive a dense hort innervation. The overall purpose of the present study, using both electrophysiological and immunocytochemical methods, was to characterize the mechanisms by which hcrts influence 5-HT neurons of the DRN. Recently, a brief communication suggested that hcrt1 excites 5-HT DRNs by a mechanism involving an activation of $\mathrm{K}^{+}$leak current (Brown et al., 2001). In contrast, our data reveal a mechanism, an $\mathrm{Na}^{+}$-dependent nonselective cation channel, not previously established for hcrt as the primary mechanism of hcrt-mediated excitation of 5-HT cells in the dorsal raphe.

In addition to these direct excitatory effects, we found that horts activated local inhibitory GABAergic input to 5-HT neurons. In accord with these electrophysiological results, immunocytochemistry showed that hort fibers projected to both 5-HT and GABAergic neurons in the DRN. Some of these results have been presented previously in abstract form (Liu et al., 2001).

\section{MATERIALS AND METHODS}

Brain slice preparation. Brain slices were prepared as described previously (Jolas and Aghajanian, 1996). Briefly, male albino rats (60-180 gm; Harlan Sprague Dawley, Indianapolis, IN) were anesthetized with chlo- 
ral hydrate $(400 \mathrm{mg} / \mathrm{kg}$, i.p.), in adherence with protocols approved by the Yale Animal Care and Use Committee. After decapitation, the brains were removed rapidly and trimmed in ice-cold $\left(\sim 4^{\circ} \mathrm{C}\right)$ artificial CSF (ACSF) in which sucrose $(252 \mathrm{~mm}$ ) was substituted for $\mathrm{NaCl}$ (sucrose-ACSF). A block of tissue containing the DRN was dissected, and coronal slices $(600 \mu \mathrm{M})$ were cut in sucrose-ACSF with an oscillating-blade tissue slicer (DSK Microslicer; Ted Pella Inc., Redding, CA). A slice containing the DRN was positioned on the stage of a fluid-gas interface chamber with the cerebral aqueduct facing an elevated fluid inlet. Fluid was wicked directly from the elevated inlet onto the slice as described previously (Burlhis and Aghajanian, 1987). The standard ACSF ( $\mathrm{pH}$ of 7.35 ), equilibrated with $95 \% \mathrm{O}_{2}$ and $5 \% \mathrm{CO}_{2}$, contained (in $\mathrm{mM}$ ): $128 \mathrm{NaCl}, 3 \mathrm{KCl}, 2 \mathrm{CaCl}_{2}, 2 \mathrm{MgSO}_{4}, 24 \mathrm{NaHCO}_{3}$, $1.25 \mathrm{NaH}_{2} \mathrm{PO}_{4}$, and $10 \mathrm{D}$-glucose. The slices were incubated at $33.0 \pm$ $0.5^{\circ} \mathrm{C}$ and perfused at a rate of $\sim 1 \mathrm{ml} / \mathrm{min}$. A $2-3 \mathrm{hr}$ recovery period was allowed before collecting data. Drug solutions, in gassed ACSF, were introduced at known concentrations through a stopcock arrangement to the recording chamber with a latency of $\sim 20 \mathrm{sec}$.

Intracellular recordings. Microelectrodes were pulled from filamentcontaining $1.5 \mathrm{~mm}$ glass tubing using a Brown and Flaming pipette puller (Sutter Instruments, Novato, CA) and filled with $2 \mathrm{M} \mathrm{KCl}$ or $2 \mathrm{M} \mathrm{CsCl}$ (30-45 M $\Omega$ ). Current-clamp and voltage-clamp recordings were made using an Axoclamp 2A or 2B amplifier coupled to a pClamp/Digidata 1200 system (Axon Instruments, Foster City, CA). In current-clamp mode, using $\mathrm{KCl}$-containing electrodes, putative serotonergic neurons were recognized by their long spike duration $(\sim 1 \mathrm{msec}$ at $50 \%$ spike amplitude) and high input resistance $(>200 \mathrm{M} \Omega)$. Previously, using a double-labeling method, neurons with these characteristics were shown to be serotonergic (Aghajanian and Vandermaelen, 1982) and to respond to 5 -HT $(100 \mu \mathrm{M})$ with a hyperpolarization $\geq 5 \mathrm{mV}$ (Aghajanian and Lakoski, 1984). All of the above criteria had to be fulfilled. For example, if a neuron had a short spike duration, it was not considered serotonergic even if it was hyperpolarized in response to 5-HT.

Voltage-clamp experiments were performed using the discontinuous single-electrode voltage-clamp mode at sampling frequencies of $5-6 \mathrm{kHz}$ and a loop gain of $10 \mathrm{nA} / \mathrm{mV}$ (30\% duty cycle). The head-stage voltage was monitored continuously to ensure that voltage transients decayed fully before the voltage was sampled; false clamping was avoided by optimizing the capacitance compensation and selecting sampling frequencies that allowed the input voltage to settle to a horizontal baseline. The cells were voltage-clamped near their resting potential $(-65 \mathrm{mV})$. Current-voltage plots ( $I-V$ curves) were obtained before and during the application of herts using slow ramps $(6 \mathrm{mV} / \mathrm{sec})$ to allow for the attainment of steady-state conditions. The ramps were generated using pClamp 8.0 software (Axon Instruments) on an IBM-AT clone. With $\mathrm{KCl}$ electrodes, spontaneous IPSCs and EPSCs both appear as inward currents because the reversal potential for chloride is shifted from approximately -70 to $-15 \mathrm{mV}$. The effects of drugs on spontaneous and hcrt-induced PSCs were sampled by recording $101 \mathrm{sec}$ episodes before and during the peak of action of the drugs.

The firing activity of 5-HT cells of the DRN in anesthetized rats in vivo is dependent on a tonically active noradrenergic system (Gallager and Aghajanian, 1976; Baraban et al., 1978). In brain slices, noradrenergic inputs are severed and 5-HT cells are usually quiescent; activity can be restored with the $\alpha_{1}$-adrenergic agonist phenylephrine (PE) (Vandermaelen and Aghajanian, 1983). Thus, PE (3 $\mu \mathrm{M})$ was added to the perfusion medium to maintain the firing of the 5-HT neuron when testing the effect of herts on the tonic spiking activity of 5-HT neurons. A previous study has shown that PE directly produces an inward current in 5-HT neurons but does not produce a change in synaptic potentials (Liu et al., 2002).

Whole-cell recordings. Whole-cell recordings were performed in 400$\mu \mathrm{M}$-thick brainstem slices containing the DRN. Slices were placed in a submerged chamber, and cells were visualized using an Olympus (Melville, NY) BX50WI (40× infrared lens; numerical aperture, 0.8) with infrared differential interference contrast microscopy (IR/DIC), as described by Stuart et al. (1993). Low-resistance patch pipettes (3-5 M $\Omega$ ) were pulled from Kovar glass tubing (World Precision Instruments, Sarasota, FL) using a Brown and Flaming horizontal puller (model P-97; Sutter Instruments) and filled with the following pipette solution (in $\mathrm{mm}$ ): $115 \mathrm{~K}$-gluconate, $20 \mathrm{KCl}, 2 \mathrm{MgSO}_{4}, 2 \mathrm{Mg}$-ATP, $2 \mathrm{Na}_{2} \mathrm{ATP}, 10$ $\mathrm{Na}_{2}$-phosphocreatine, $0.3 \mathrm{Na}_{2} \mathrm{GTP}$, and 10 HEPES, pH 7.33. Recordings of visualized small $(10 \mu \mathrm{m})$, non-5-HT neurons were made in currentclamp (bridge) mode with an Axoclamp-2B amplifier (Axon Instruments). Recordings of miniature IPSCs (mIPSCs) in 5-HT cells were made with a pipette solution that contained $85 \mathrm{~mm} \mathrm{KCl}$ rather than the usual $20 \mathrm{~mm}$ (with a corresponding reduction in K-gluconate). Under these conditions, because of a positive shift in $\mathrm{Cl}^{-}$equilibrium potential, the amplitude of mIPSCs is enhanced and appears as inward currents when cells are clamped at -60 to $-70 \mathrm{mV}$. The output signal was low-pass-filtered at $3 \mathrm{kHz}$, amplified $100 \times$ through Cyberamp, digitized at $15 \mathrm{kHz}$, and acquired using pClamp/Digidata 1200 (Axon Instruments)

Immunocytochemistry. To study the hert innervation of the DRN, six adult albino rats were given an overdose of pentobarbital (Nembutal; 150 $\mathrm{mg} / \mathrm{kg}$ ) and perfused transcardially with physiological saline, followed by $4 \%$ paraformaldehyde; in two additional rats, $0.25 \%$ glutaraldehyde was added to the perfusion fixative. After overnight fixation, $30 \mu \mathrm{m}$ sections were cut on a vibratome, washed in PBS, and treated with $1 \%$ bovine serum albumin, $0.1 \%$ glycine, $0.1 \%$ lysine, and $0.3 \%$ Triton $\mathrm{X}-100$.

Sections were incubated overnight in one of several different antisera, including rabbit anti-5-HT (1:3000; ImmunoNuclear, Stillwater, MN) or guinea pig anti-serotonin transporter (1:3000; Chemicon, Temecula, CA) to reveal 5-HT neurons (Blakely et al., 1991), rabbit anti-hcrt-2 (1:3500) (van den Pol et al., 1998) or goat anti-orexin-B (1:4000) (Santa Cruz Biochem, Santa Cruz, CA) to reveal hcrt-containing axons, rabbit antiGABA (1:2500; gift from T. Gorcs, Semmelweis University, Budapest, Hungary) (described by Decavel and van den Pol, 1990), or rabbit anti-GABA transporter (1:2500; Chemicon) that is produced selectively in GABA neurons (McIntire et al., 1997). After six buffer washes, sections were immersed in a secondary anti-guinea pig conjugated to Texas Red (1:175; Molecular Probes, Eugene, OR) and anti-rabbit conjugated to fluorescein (1:125; Molecular Probes), resulting in greenlabeled hort fibers and red-labeled 5-HT cells. For double labeling of GABA cells of hort fibers, goat anti-orexin antisera were used for hert axons, a combination of rabbit anti-GABA transporter and rabbit antiGABA were used to reveal GABA immunoreactive cells, and goat anti-orexin was used to reveal hcrt fibers; secondary antisera of FITC or Alexa-488-conjugated donkey anti-goat revealed green-labeled hcrt axons and boutons, and Alexa-546- or Alexa-594-conjugated donkey antirabbit revealed red-labeled GABA immunoreactive cells.

Cross reaction of the two sets of immunoreagents used for double immunofluorescence was controlled by using primary antisera raised in different species followed by two species-selective and affinity-purified secondary antisera, each conjugated to a different fluorescent label, that bound specifically to the species in which the primary antisera was raised. Immunostaining of structures in the DRN with double labeling was consistent with staining with single-label immunostaining.

Sections were mounted on glass slides, and photomicrographs were taken with a Spot-2 digital camera (Diagnostic Instruments Inc., Sterling Heights, MI) interfaced with a Macintosh computer. Images were imported into Photoshop (Adobe Systems, San Jose, CA), with which the contrast and brightness were corrected; images were printed on an Epson 900 digital printer (Epson Corp.).

Drugs. Tetrodotoxin (TTX) was obtained from Alomone Labs (Jerusalem, Israel); 5-HT was from Sigma (St. Louis, MO); bicuculline methiodide (Bic) and 6-cyano-7-nitroquinoxaline-2,3-dione (CNQX) were from Research Biochemicals (Natick, MA); bis(2-aminophenoxy)ethane$N, N, N^{\prime}, N^{\prime}$-tetra-acetic acid (BAPTA) was from Molecular Probes; 2-[2[4-(4-nitrobenzyloxy)phenyl]ethyl]isothiourea mesylate (KB-R7943) was from Kanebo Co. Ltd. (Osaka, Japan); hcrt2 (orexin-B) was synthesized at Stanford University (Stanford, CA); and hort1 (orexin-A) was from Phoenix Pharmaceuticals (Mountain View, CA). All drug solutions were perfused at known concentrations through a stopcock assembly.

Analysis and statistics. Data were displayed off-line with Clampfit software of pClamp 8.0 (Axon Instruments). For statistical evaluation, we used a paired or unpaired Student's $t$ test; results are presented as means \pm SE. Analysis of PSC frequency and amplitude was conducted with commercially available Mini Analysis software (Synaptosoft Inc., Decatur, GA). This program detects and measures spontaneous synaptic events according to the amplitude, rate of rise, duration, and area under the curve (fc). Synaptic events were detected with an amplitude threshold of $5 \mathrm{pA}$ and area threshold of $50 \mathrm{fc}$. Statistical comparisons of the extracted amplitude and interspike interval distributions for PSCs were conducted with the nonparametric Kolmogorov-Smirnov (K-S) test. This test gives a measure of the relative dispersion between two distributions (Goodman, 1954). Cumulative probability distributions were considered significantly different with a $p$ value of $<0.01$ (K-S test). 

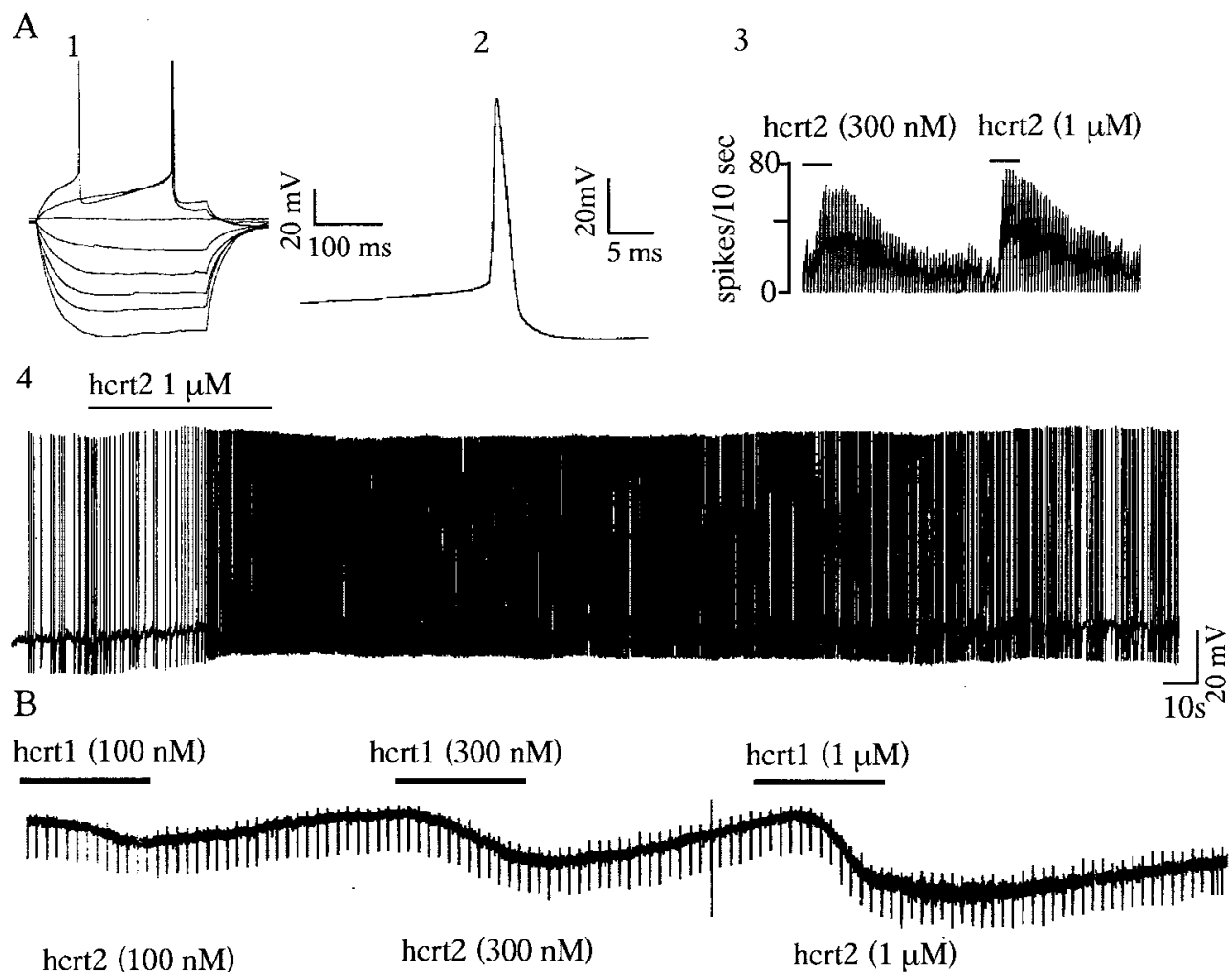

Figure 1. Hcrts increase spiking and induce an inward current in 5-HT neurons of the DRN. $A$, Whole-cell currentclamp recording showing that hort2 increases spiking in a 5 -HT neuron. $A 1$, Response of a 5-HT-type neuron to depolarizing and hyperpolarizing current steps (step size, $-0.05 \mathrm{nA}$; maximum step, $-0.25 \mathrm{nA}) . A 2$, Note the long spike duration of this cell $(1.02 \mathrm{msec}$ at half amplitude), which is typical of 5-HT neurons. A3, Rate record showing that this 5-HT neuron responds to hort2 with a 200 and $243 \%$ increase in firing rate to $300 \mathrm{nM}$ hert2 and $1 \mu \mathrm{M}$ hert2, respecC

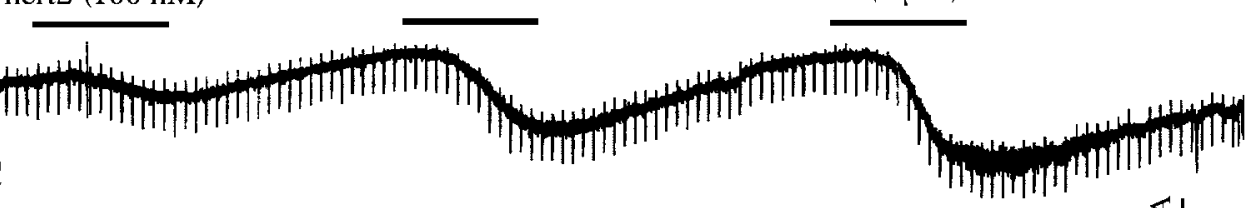
tively. $A 4$, Continuous recording from the same cell showing an increase in firing after $1 \mu \mathrm{M}$ hcrt2 (basal firing was maintained by $3 \mu \mathrm{M}$ PE; see Materials and Methods). $B$, Voltage-clamp traces from a 5-HT neuron $\left(V_{\mathrm{h}}=-65 \mathrm{mV}\right)$ showing inward currents generated by hert 1 and hort 2 at $100 \mathrm{~nm}, 300 \mathrm{~nm}$, and 1 $\mu \mathrm{M}$. To avoid desensitization, a full recovery to baseline was allowed between successive applications of hcrts. $C$, Concentration-dependent responses to different concentrations of hert1 and hcrt2. Note that at each concentration, inward current amplitudes are not different for hort1 and hort2 $(p>0.05$; $n=10$ at $100 \mathrm{nM}$ to $1 \mu \mathrm{M} ; n=5$ at $3 \mu \mathrm{M}$; unpaired $t$ test).

\section{RESULTS}

Intracellular recordings were obtained from 180 neurons located in the DRN; of these, 120 met the criteria for classification as serotonergic. The latter cells had the following characteristics: long spike duration ( $0.99 \pm 0.01 \mathrm{msec}$ at half amplitude), a hyperpolarizing response to $100 \mu \mathrm{M} 5$-HT ( $\geq 5 \mathrm{mV}$ ), an average resting potential of $-62.4 \pm 1.4 \mathrm{mV}$, a mean action potential amplitude of $92.1 \pm 1.1 \mathrm{mV}$, and high input resistance (230.1 \pm 8.8 $\mathrm{M} \Omega$ ), as described previously (see Materials and Methods). The cells that met these criteria were used for the experiments with hcrts. In addition, whole-cell recordings were obtained from 36 neurons visualized by IR/DIC in the DRN. Of these, 19 met the criteria for classification as 5-HT cells. As described below, the remaining 17 cells were identified as non-5-HT on the basis of their small size $(\sim 10 \mu \mathrm{m})$ and short-duration action potentials (0.3-0.5 msec at half amplitude) and by the absence of a hyperpolarizing response to $5-\mathrm{HT}$.

\section{Hcrts increased spiking and evoked an inward current in 5-HT neurons of the DRN}

In current-clamp mode, bath application of hert1 or hert 2 increased the tonic firing of 5-HT cells maintained in the presence of $3 \mu \mathrm{M}$ PE (Fig. 1A) (see Materials and Methods). This effect was concentration dependent, with a mean increased rate induced by hert 2 of $109 \pm 12 \%$ at $100 \mathrm{nM}, 200 \pm 17 \%$ at $300 \mathrm{nM}$, and $240 \pm$ $15 \%$ at $1 \mu \mathrm{M}(n=5)$. Similar effects were obtained with hcrt1.

To examine these excitatory effects in greater detail, subsequent experiments were conducted under voltage-clamp condi- 
Figure 2. Hcrt-induced inward currents are insensitive to TTX, whereas hort-induced PSCs are blocked by TTX. $A 1$, Inward currents evoked by bath application of hert1 and hort2 (both $1 \mu \mathrm{M}$ ) are not blocked by TTX $(2 \mu \mathrm{M})$ added to the bath. $A 2(5 \mathrm{~min})$, Data from five cells tested with each peptide. $B 1$, In this 5-HT cell, in addition to an inward current, there was a marked thickening of the trace in response to hert2. B2, With faster traces at a higher gain, it can be seen that the latter was attributable to a marked increase in the frequency of PSCs. After TTX (5 min), the PSCs were abolished, but the inward current remained undiminished. $C$, Whole-cell recording illustrating the lack of effect of horts on either the frequency or amplitude of spontaneous miniature PSCs recorded in the presence of TTX (see Results for details).
A 1

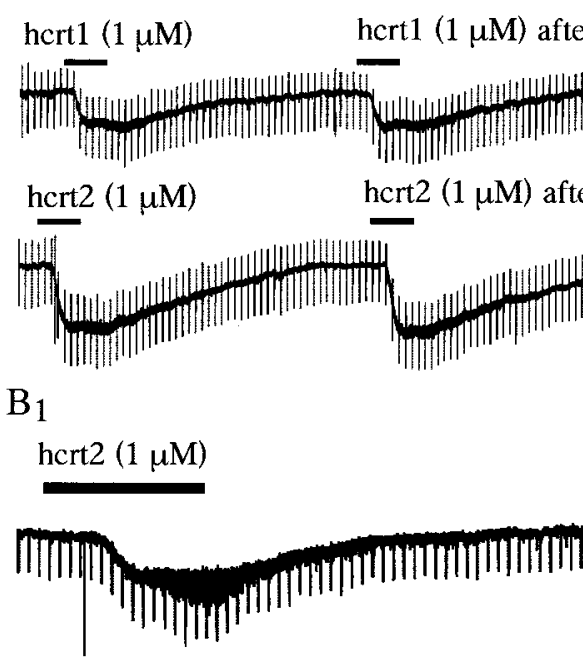

2

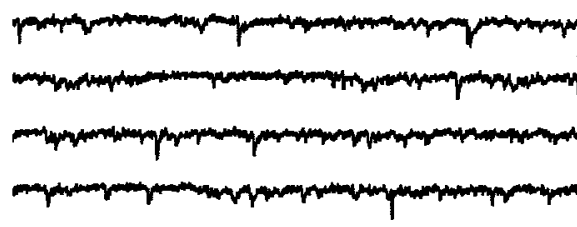

TTX $2 \mu \mathrm{M}$
$2 \quad$ 므hert-1

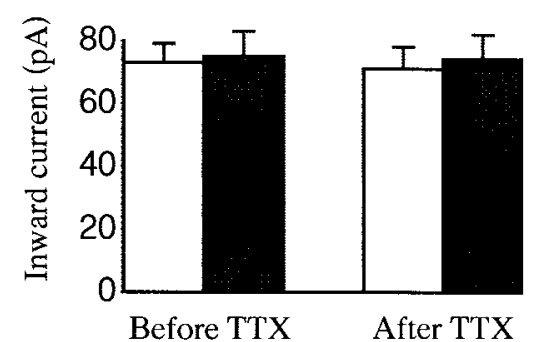

造

hert2 $(1 \mu \mathrm{M})$ after TTX

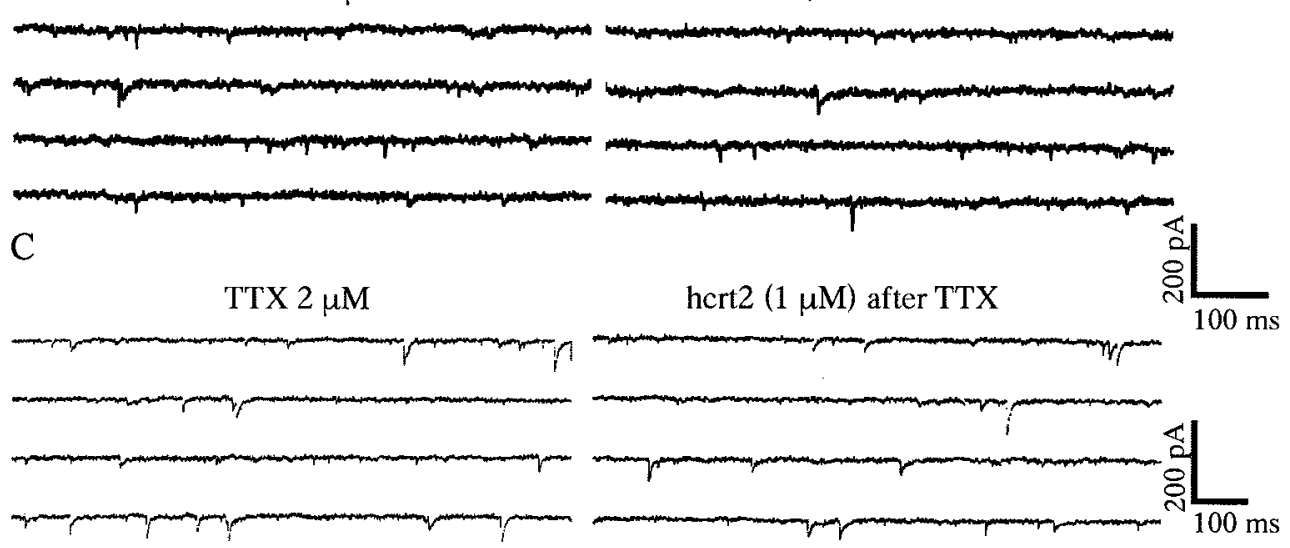

tions. When the membrane potential was voltage-clamped at or near its resting level, both hort1 and hort 2 produced a reversible inward current in approximately two-thirds of the neurons tested $(n=83)$ (Fig. 1). The peak inward current evoked by horts $(1 \mu \mathrm{M}$ for $2.5 \mathrm{~min}$ ) ranged from 20 to $180 \mathrm{pA}$ (mean current for hcrt1, $73 \pm 16 \mathrm{pA}, n=32$; mean current for hcrt $2,75 \pm 13 \mathrm{pA}, n=38)$. The current slowly increased in amplitude, reached its peak value within 1.5-2 min, remained at this level $\sim 1-2 \mathrm{~min}$, and slowly recovered over 7-10 min after the application was discontinued. No consistent change in membrane conductance was observed in this voltage range. The action of hcrt1 and hcrt 2 was concentration dependent, with a threshold near $100 \mathrm{nM}$, an $\mathrm{EC}_{50}$ near 250 $\mathrm{nM}$, and a saturation near $1 \mu \mathrm{M}$. In contrast to some regions of the brain (see Discussion), there was no significant difference between the response to hort 1 and hort 2 in the raphe (Fig. 1C). The inward current induced by hort1 and hcrt2 was insensitive to the fast $\mathrm{Na}^{+}$channel blocker TTX (Fig. $\left.2 A 1, A 2\right)(p>0.05 ; n=5$ per group; paired $t$ test). Figure $2 B$ shows an hort-sensitive 5-HT neuron in which responses were accompanied by an increase in baseline thickening (Fig. 2B1). Fast traces showed that the latter was attributable primarily to a large increase in the frequency of PSCs (Fig. 2B2). After $5 \mathrm{~min}$ of $2 \mu \mathrm{M}$ TTX, the PSCs were abolished, but the inward current remained undiminished. As can be seen in Figure 2B, despite the suppression of PSCs by TTX, there was some residual thickening, which is evident in the slow trace but not in the fast traces. This implies that the thickening that remained after TTX may be attributable to slow oscillations in membrane potential; this phenomenon was not explored further.

\section{Ionic mechanism for the hcrt-induced inward current}

To test for a possible mechanism involving a $\mathrm{Ca}^{2+}$-dependent release of transmitter substances, a nominally $\mathrm{Ca}^{2+}$-free/high$\mathrm{Mg}^{2+}(10 \mathrm{~mm}) \mathrm{ACSF}$ was used. In the $\mathrm{Ca}^{2+}$-free/high- $\mathrm{Mg}^{2+}$ solution, the inward current evoked by horts not only persisted but was enhanced in $80 \%$ of neurons tested (Fig. 3) $(n=14)$. In 
A

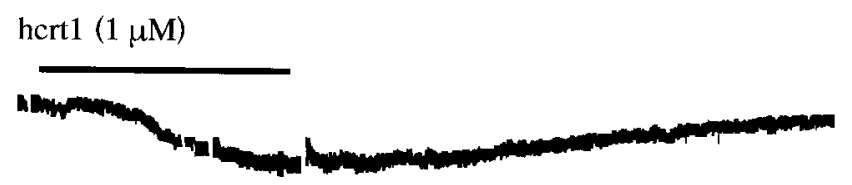

hcrt1 $(1 \mu \mathrm{M}) / \mathrm{calcium}-$ free/high-magnesium

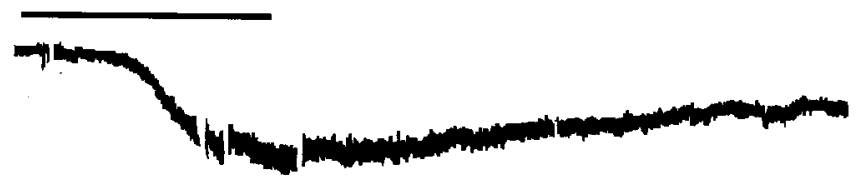

B

hert2 $(1 \mu \mathrm{M})$

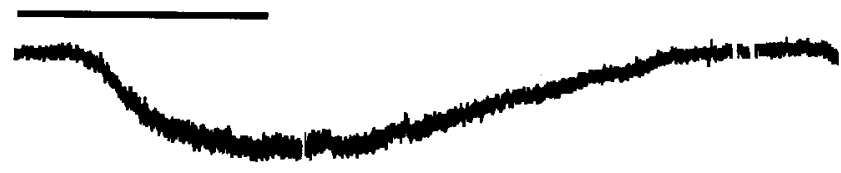

hcrt2 $(1 \mu \mathrm{M}) /$ calcium-free/high-magnesium

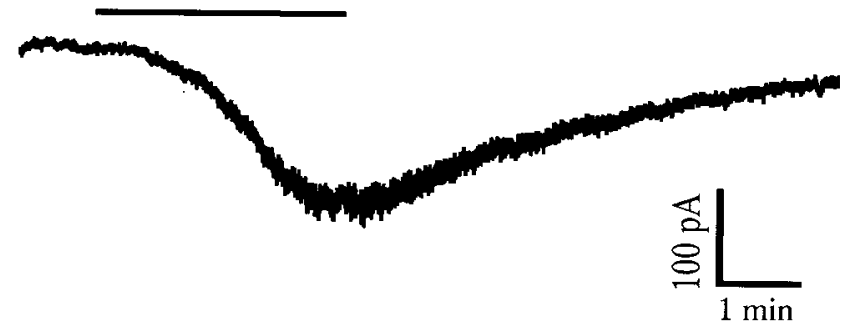

Figure 3. Inward currents induced by herts persist in a nominally $\mathrm{Ca}^{2+}$ free/high- $\mathrm{Mg}^{2+}(10 \mathrm{~mm})$ solution. Current traces $\left(V_{\mathrm{h}}=-65 \mathrm{mV}\right)$ from 5-HT neurons showing an inward current induced by $1 \mu \mathrm{M}$ hort1 $(A)$ or 1 $\mu \mathrm{M}$ hert2 $(B)$ before and during the application of a nominally $\mathrm{Ca}^{2+}$ free/high- $\mathrm{Mg}^{2+}$ solution. Note that the responses to hort1 and hort2 are enhanced rather than reduced in the $\mathrm{Ca}^{2+}$-free/high- $\mathrm{Mg}^{2+}$ solution. Also note that, as with TTX, there was a thickening of the trace during hert application despite a block of synaptic potentials.

normal ACSF, the peak currents evoked by hort1 and hort 2 were $82 \pm 11.3 \mathrm{pA}(n=5)$ and $83 \pm 8.6 \mathrm{pA}(n=5)$, respectively. During superfusion with a $\mathrm{Ca}^{2+}$-free/high- $\mathrm{Mg}^{2+}$ solution, there was an approximately twofold increase in the hort1 current (173 $\pm 12.3 .2 \mathrm{pA} ; p<0.05 ; n=7$; paired $t$ test) and hcrt 2 current $(170 \pm 16.4 \mathrm{pA} ; p<0.05 ; n=5$; paired $t$ test $)$. This effect could be reversed by reperfusion of the preparation with the normal ACSF. Voltage ramps in the -60 to $-120 \mathrm{mV}$ range show a parallel shift in the hort $I-V$ curve, indicating no change in voltage sensitivity (data not shown). From these data, we conclude that: (1) the inward current induced by horts in the DRN is not secondary to a $\mathrm{Ca}^{2+}$-dependent release of neurotransmitter and (2) extracellular calcium ions do not themselves carry a significant part of the hcrt-induced current. The increased response in the low $\mathrm{Ca}^{2+}$ solution is consonant with findings in other systems that $\mathrm{Ca}^{2+}$ removal enhances nonselective cation currents, possibly by removal of the $\mathrm{Ca}^{2+}$ inhibition of the channel (Raggenbass and Dreifuss, 1992; Formenti et al., 2001).

To test for the contribution of $\mathrm{Na}^{+}$to the hort-induced inward current, we substituted choline chloride for extracellular $\mathrm{NaCl}$. Because total $\mathrm{Na}^{+}$substitution impairs ambient excitatory amino acid uptake (Parsons et al., 1992), we could replace only $80 \%$ of the total $\mathrm{Na}^{+}$(Shen and North, 1992). The inward current induced by horts was assessed with a voltage ramp protocol ( -60 to $-120 \mathrm{mV}$ ) before (ramp 1) and during (ramp 2) the application of hcrts. Under control conditions, the mean peak currents induced by hort 1 and hert 2 were $73 \pm 8 \mathrm{pA}(n=5)$ and $75 \pm 9 \mathrm{pA}(n=$ $5)$, respectively. In all cells, the hort response was largely eliminated after $\mathrm{Na}^{+}$substitution with choline (Fig. 4A,B): the mean currents became $13.7 \pm 3.2 \mathrm{pA}(p<0.05 ; n=5$; paired $t$ test $)$ for hort1 and $14.5 \pm 4.6 \mathrm{pA}(p<0.05 ; n=5$; paired $t$ test $)$ for hort2. This $>80 \%$ reduction indicates that hert-induced inward currents are carried primarily by $\mathrm{Na}^{+}$. This effect of choline reversed after switching back to regular ACSF containing normal $\mathrm{Na}^{+}$. To rule out a possible cholinergic effect of choline, $\mathrm{Na}^{+}$substitution was also performed with Tris hydrochloride: in four neurons tested, the results were virtually identical to those using choline substitution. In three of five neurons, $I-V$ curves suggestive of a small residual current appeared to reverse near $E_{\mathrm{K}}$ (approximately $-100 \mathrm{mV}$ ) (Fig. 4B). However, the latter was not studied further because of its inconsistency, small size, and inability to eliminate $\mathrm{Na}^{+}$-dependent currents entirely.

To determine whether the hcrt-induced inward current reversed in the depolarizing direction, 5-HT neurons were recorded using micropipettes filled with $\mathrm{CsCl}$ instead of $\mathrm{KCl}$. CsCl blocks inwardly rectifying $\mathrm{K}^{+}$channels and the large delayed rectifier $\mathrm{K}^{+}$currents that normally occur in the depolarizing range. Cells were clamped at $0 \mathrm{mV}$, and slow hyperpolarizing ramps $(6 \mathrm{mV}$ ) sec) were used to plot the $I-V$ relationship before and during application of hcrts. Note that it was not necessary to use TTX to prevent repetitive spiking when holding cells at $0 \mathrm{mV}$ because blockade of the delayed rectifier prevents repolarization and removal of $\mathrm{Na}^{+}$channel inactivation. $I-V$ curves $(0$ to $-60 \mathrm{mV})$ were obtained at baseline and near the peak of the hcrt-induced inward current. In five of seven neurons tested, voltage ramps with $\mathrm{CsCl}$ pipettes showed a mean reversal potential near $-18.8 \pm 3.5 \mathrm{mV}$ $(n=5)$ (Fig. 4C), which is typical of a nonspecific cation conductance. Analysis of the conductance change of these currents by subtracting the hort from the baseline curve showed a linear $I-V$ relationship in this voltage range (Fig. $4 C$ ), with a mean increase in slope conductance of $24.7 \pm 0.3 \%(n=5)$.

The above results are consistent with a nonselective cation channel as the basis for the hcrt-induced inward current. However, another mechanism that conceivably could contribute to the TTX-insensitive $\mathrm{Na}^{+}$-dependent inward current would be the electrogenic $\mathrm{Na}^{+} / \mathrm{Ca}^{+}$exchanger, which is also dependent on extracellular $\mathrm{Na}^{+}$and a similar reversal potential (Ehara et al., 1989). To assess that possibility, we used the $\mathrm{Na}^{+} / \mathrm{Ca}^{+}$exchange inhibitor KB-R7943 (Watano et al., 1996). At a low concentration $(10 \mu \mathrm{M}), \mathrm{KB}-\mathrm{R} 7943$ had no effect on the inward current, but at a higher concentration $(30 \mu \mathrm{M})$ there was a modest reduction in the inward current $(-15$ to $20 \% ; n=4)$. However, complicating the interpretation of these data are reports that KB-R7943 has nonspecific actions at various ion channels and ion transport systems (Iwamoto et al., 1996; Watano et al., 1996; Sobolevsky and Khodorov, 1999). As an alternative approach, we used the fact that the inward current mediated by the $\mathrm{Na}^{+} / \mathrm{Ca}^{+}$exchanger (Ehara et al., 1989), but not the nonselective cation channel (Farkas et al., 1996), is dependent on the availability of intracellular $\mathrm{Ca}^{2+}$. Whole-cell voltage-clamp recordings $\left(V_{\mathrm{h}}=-65 \mathrm{mV}\right)$ were conducted in 5-HT cells with a pipette solution containing 5-10 mM BAPTA, a high-affinity $\mathrm{Ca}^{2+}$ chelator. There was no reduction in the inward current induced by hert2 $(1 \mu \mathrm{M})$ in BAPTA-loaded cells (95 $\pm 14.4 \mathrm{pA} ; n=4)$ compared with cells 
A

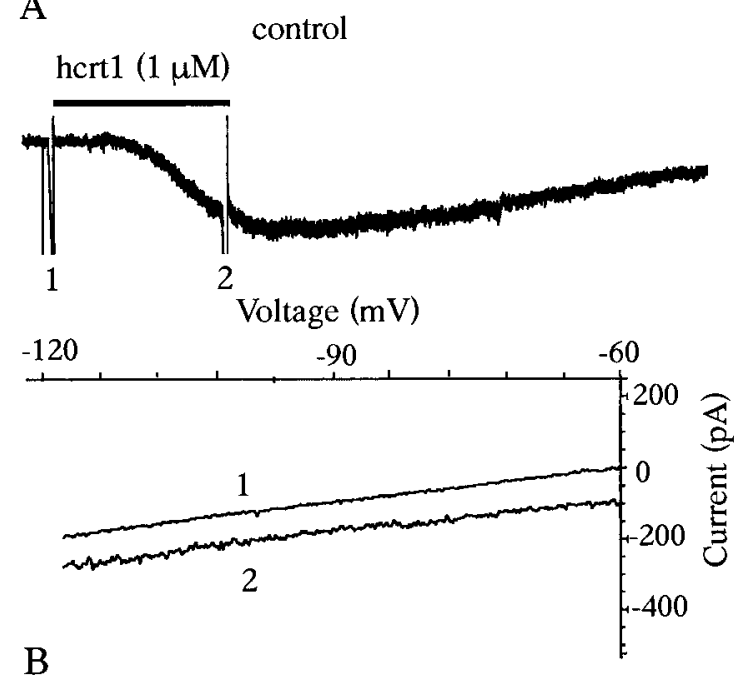

control

hert2 $(1 \mu \mathrm{M})$

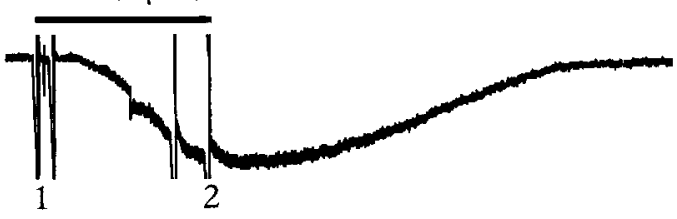

Voltage (mV)

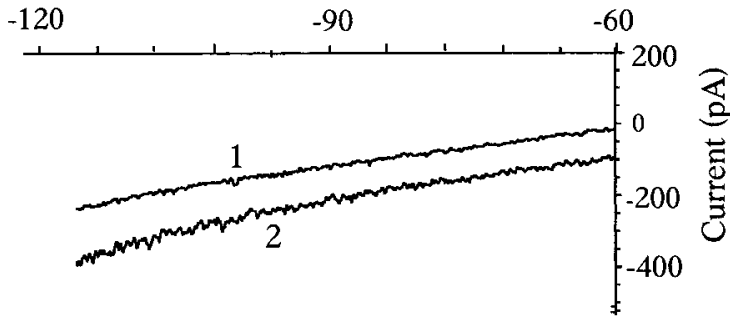

C

$\mathrm{CsCl}$ pipettes

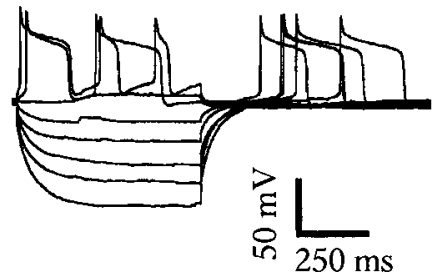

low sodium

$\downarrow \quad$ hert1 $(1 \mu \mathrm{M})$

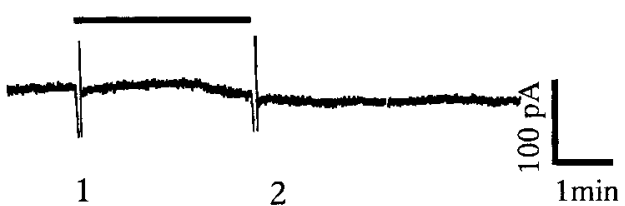

Voltage $(\mathrm{mV})$
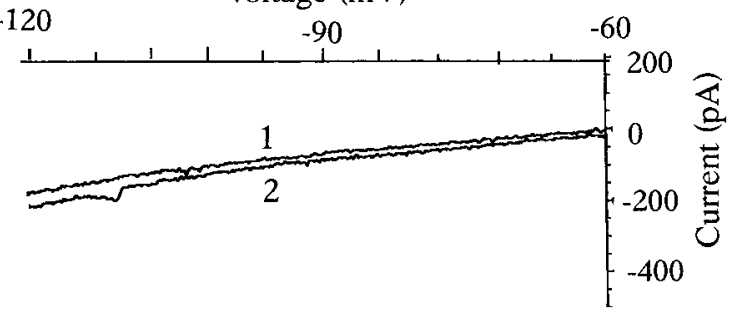

low sodium

$\downarrow$

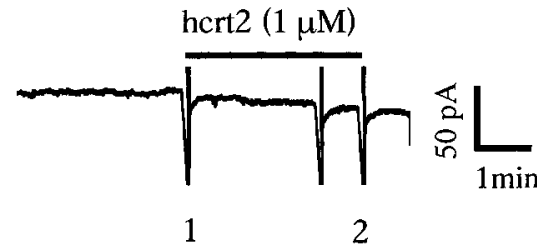

Voltage $(\mathrm{mV})$

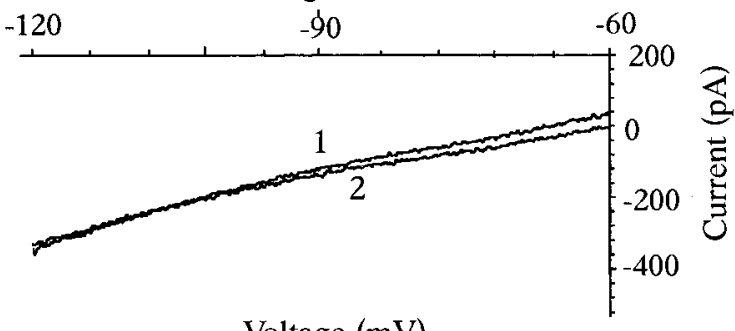

Voltage $(\mathrm{mV})$
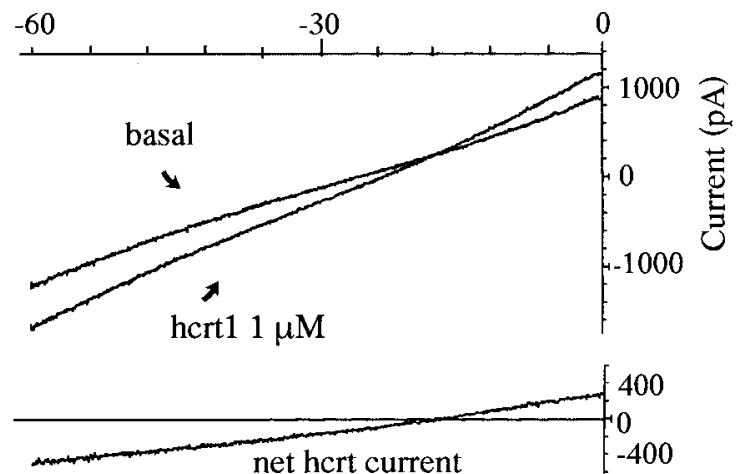

Figure 4. Marked reduction in hert-induced inward currents after $\mathrm{Na}^{+}$substitution. $A$, Bath application of $1 \mu \mathrm{M}$ hcrt1 produced a $100 \mathrm{pA}$ inward current that did not reverse in the voltage range tested $(-60$ to $-120 \mathrm{mV})$. After the replacement of $\mathrm{Na}^{+}-\mathrm{ACSF}$ with choline-ACSF, the hcrt1-induced current was much reduced, and the remaining current did not reverse in this range. $B$, In another 5-HT neuron, bath application of hcrt2 (1 $\mu \mathrm{M})$ produced a 85 pA inward current that did not reverse in the voltage range tested. After replacement of $\mathrm{Na}^{+}$-ACSF with choline-ACSF, the hcrt2-induced current was reduced, and the remaining hert current reversed near $E_{\mathrm{K}}$ (approximately $-100 \mathrm{mV}$ ). $C$, An hcrt-sensitive 5-HT neuron recorded with a CsCl-containing electrode $(2 \mathrm{M})$. Current-clamp recording shows marked widening of spikes secondary to $\mathrm{CsCl}$ block of delayed rectifier $\mathrm{K}^{+}$currents (see Materials and Methods). Slow hyperpolarizing voltage ramps $(6 \mathrm{mV} / \mathrm{sec})$ from 0 to $-60 \mathrm{mV}$ obtained before and during peak of the hcrt-induced inward current are shown. A subtraction trace (bottom right) shows that the hort1-induced current reverses near $-20 \mathrm{mV}$. 
recorded with standard pipette solution $(72 \pm 8 \mathrm{pA} ; n=5)$. These results indicate that the $\mathrm{Na}^{+} / \mathrm{Ca}^{+}$exchanger does not contribute significantly to the hort-induced inward current.

\section{Hcrts induce an increase in spontaneous IPSCs in serotonin cells of the DRN}

In addition to inducing an inward current, hert1 and hert 2 both produced an increase in spontaneous PSCs in almost half of the cells that met the criteria for classification as 5-HT neurons (Fig. $5 A, B)(n=58$ of 123$)$. Under basal conditions, the spontaneous PSC frequency was $3.2 \pm 0.6 \mathrm{~Hz}$ and the amplitude was $57.5 \pm 2$ pA $(n=58)$. Both hort1 $(1 \mu \mathrm{M})$ and hort2 $(1 \mu \mathrm{M})$ significantly increased the mean PSC frequency to $10.4 \pm 0.8$ and $10.9 \pm 1.2$ $\mathrm{Hz}$, respectively ( $p<0.001 ; n=58$; paired $t$ test) and the amplitude to $73.9 \pm 6.4$ and $71.8 \pm 8.2 \mathrm{pA}$, respectively $(p<0.05$; $n=53$; paired $t$ test). The induction of PSCs by horts was found to be concentration dependent (100 nM to $10 \mu \mathrm{M}$ ), with an $\mathrm{EC}_{50}$ of $0.61 \mu \mathrm{M}$ for hort1 and $0.45 \mu \mathrm{M}$ for hort2 (Fig. $5 C)(n=10)$. Under our intracellular recording conditions using $\mathrm{KCl}$-filled peptides, $\mathrm{Cl}^{-}$currents are reversed and both EPSCs and IPSCs appear as inward currents. Therefore, we used receptor-selective antagonists to determine whether the hcrt-induced PSCs were excitatory or inhibitory. In the great majority of responsive cells (47 of 58), the hert-induced PSCs were insensitive to CNQX, a blocker of AMPA/kainate-type glutamate receptors, but were blocked completely by application of the $\mathrm{GABA}_{\mathrm{A}}$ receptor antagonist bicuculline (10 $\mu \mathrm{M}, 4$ min application) (Fig. 6), indicating that they were $\mathrm{GABA}_{\mathrm{A}}$-mediated IPSCs. The rise time of the IPSCs was $0.92 \pm 0.01 \mathrm{msec}$ and the time constant decay was $3.3 \pm 0.02 \mathrm{msec}$. In a minority of neurons (11 of 58$)$, herts also induced an increase in EPSC frequency, as indicated by sensitivity to CNQX.

To determine whether hcrts increased the frequency of miniature PSCs, we conducted whole-cell recordings in the presence of TTX to block impulse flow-dependent PSCs. As shown in Figure $2 C$, miniature PSCs did not increase in response to hort in 5-HT neurons ( $p>0.05 ; n=5$; paired $t$ test).

\section{Hcrts directly excite GABA interneurons}

The TTX sensitivity of the hcrt-induced increase in IPSC frequency in 5-HT neurons suggests that horts can directly excite GABAergic interneurons in the DRN. This hypothesis was tested using whole-cell recordings from non-5-HT neurons visualized by IR/DIC in the DRN. As mentioned above, the non-5-HT cells were selected on the basis of their small size $(\sim 10 \mu \mathrm{m})$ and short-duration action potentials $(0.3-0.5 \mathrm{msec}$ at half amplitude) and by the absence of a hyperpolarizing response to applied 100 $\mu \mathrm{M}$ 5-HT. Of 17 non-5-HT cells tested, eight neurons also exhibited a depolarizing sag in the electrotonic response to hyperpolarizing pulses (Fig. $7 A)$. In all of the latter cells, hort2 $(1 \mu \mathrm{M})$ increased basal firing (mean increase, $152 \pm 11 \%$ ) (Fig. $7 B$ ). Hcrts also induced an inward current in these neurons, ranging from 10 to $40 \mathrm{pA}$ (data not shown). The remaining nine non5-HT cells did not respond to hert.

\section{Hcrt input to both 5-HT and GABA neurons}

Consistent with the electrophysiological results, immunocytochemistry showed that hert fibers projected to both 5-HT and GABA neurons in the DRN. As reported previously in a general survey of hort fibers in the brain (Peyron et al., 1998), a high density of hort fibers was found within the DRN, as shown in Figure $8 A$. Both 5-HT vesicular-transporter immunoreactive red fluorescent cells and fibers were found in the DRN. 5-HT immu-
A
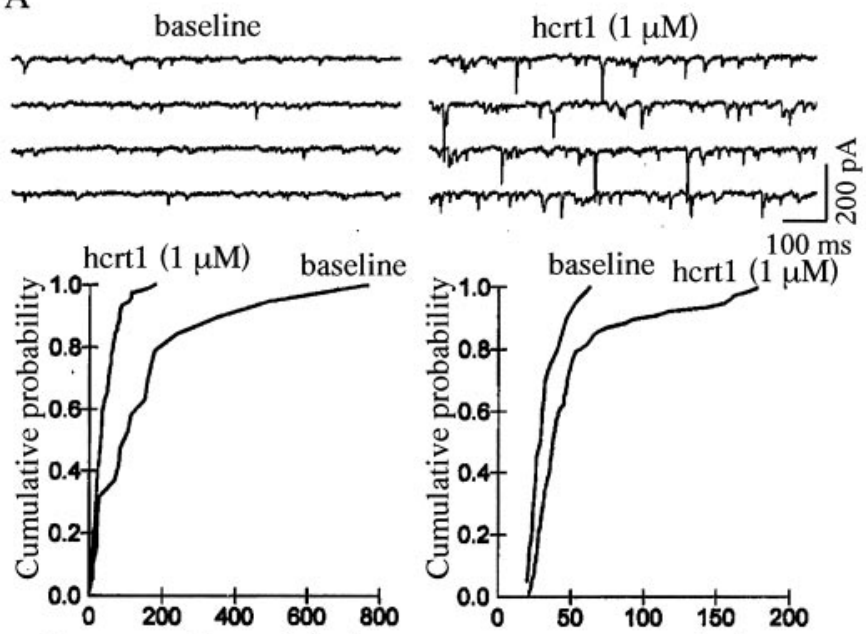

Inter-event interval $(\mathrm{ms})$

B
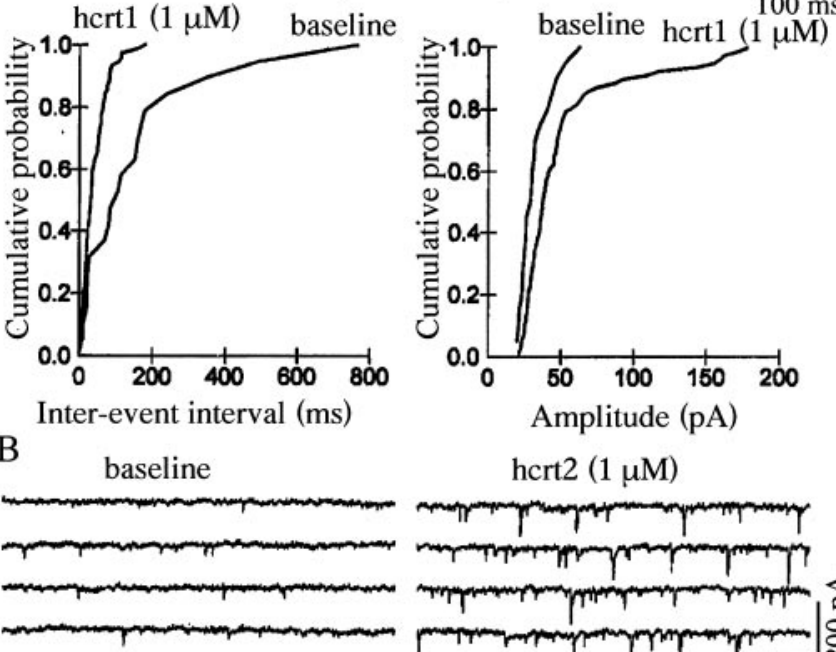

Amplitude (pA)
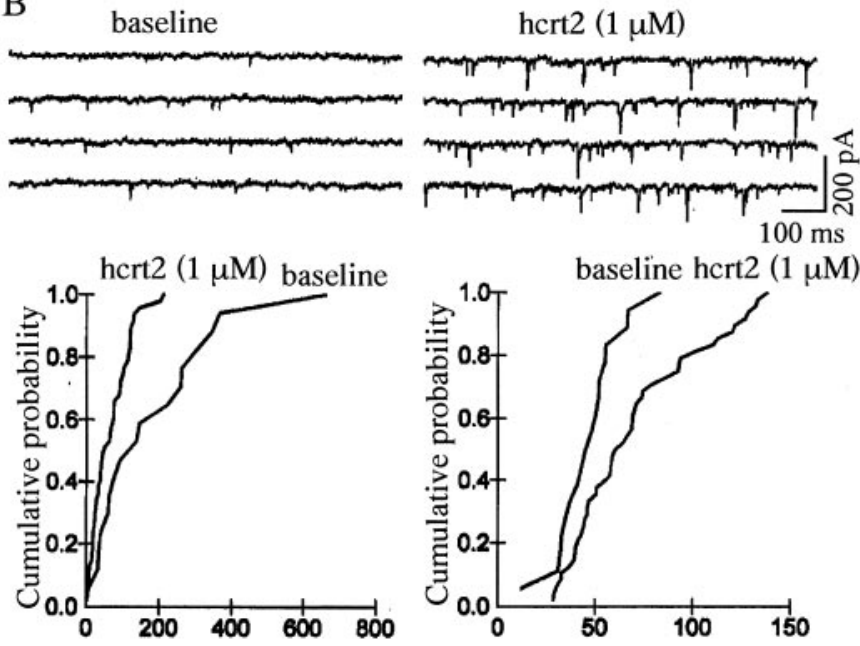

C

Inter-event interval (ms)

Amplitude (pA)

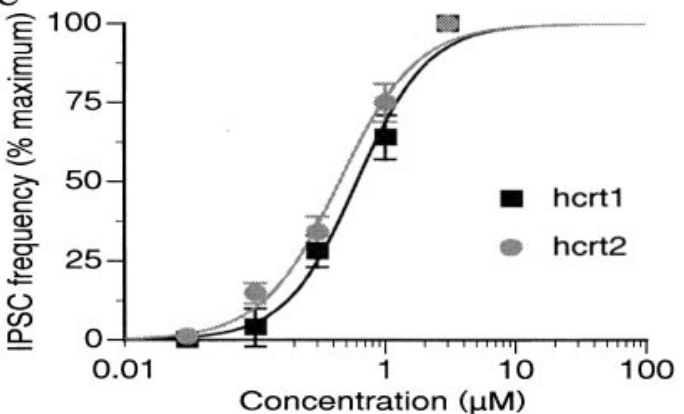

Figure 5. Hcrts induce an increase in PSCs in 5-HT cells of the DRN. A, Top traces show an increase in PSCs induced by hert1 in a voltageclamped 5-HT cell $\left(V_{\mathrm{h}}=-65 \mathrm{mV}\right)$. Below are normalized cumulative distributions of PSC amplitude and interevent intervals for this cell before and during the application of hcrt1 (data taken from $101 \mathrm{sec}$ episodes for each condition; differences; $p<0.001 ; \mathrm{K}-\mathrm{S}$ test). $B$, Top traces show an increase in PSCs induced by hort2; the normalized cumulative distributions of PSC amplitude and interevent intervals are shown below (differences; $p<0.001 ; \mathrm{K}-\mathrm{S}$ test). $C$, Concentration-response curve $(0.03,0.1$, $0.3,1$, and $3 \mu \mathrm{M}$ ) for two groups of five DRN 5-HT cells in which the hcrts induced an increase in IPSC frequency. The $\mathrm{EC}_{50}$ was $0.6 \mu \mathrm{M}$ for hert1 and $0.45 \mu \mathrm{M}$ for hert2. 
A

baseline

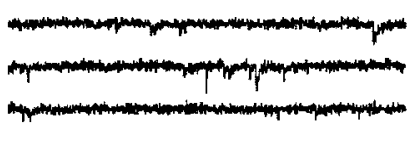

bicuculline $(10 \mu \mathrm{M})$.

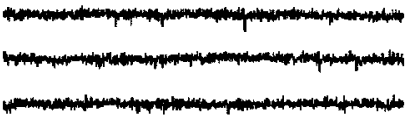

B

washout

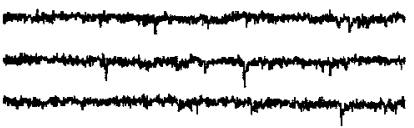

bicuculline $(10 \mu \mathrm{M})$

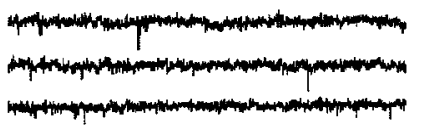

$\mathrm{C}$

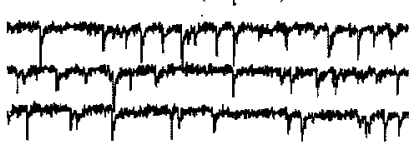

bicuculline + hert 2

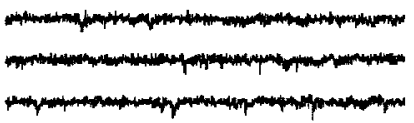

hort1 $(1 \mu \mathrm{M})$

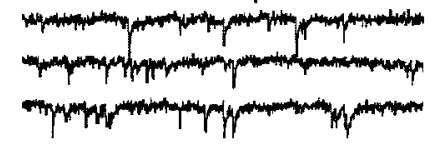

bicuculline + hcrt1
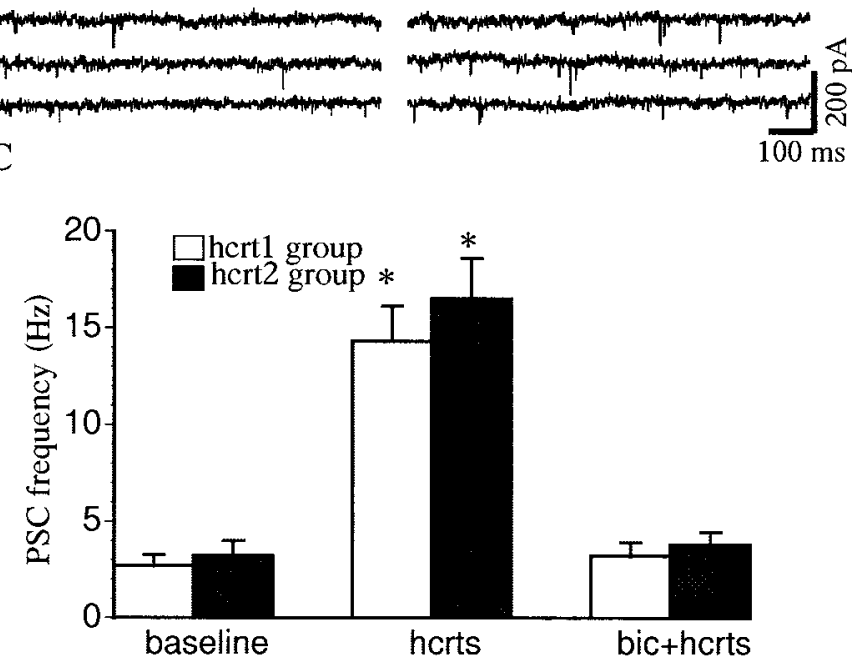

Figure 6. Bicuculline blocks PSCs induced by hert1 and hert2. A, An hcrt1-induced increase in PSC frequency was blocked by bicuculline (10 $\mu \mathrm{M}) . B$, After prolonged washout, hert 2 induced an increase in PSC frequency in the same cell, which was also blocked by bicuculline $(10 \mu \mathrm{M})$. The traces display three consecutive $1 \mathrm{sec}$ episodes. $C$, Bicuculline blocked the increase in PSC frequency induced by hert1 or hort2 $(p<$ 0.005; $n=47$; paired $t$ test). The basal PSC frequency in this sample was $2.8 \mathrm{~Hz}$. The plots demonstrate that PSCs induced by herts are GABAergic IPSCs. ${ }^{*} p<0.05$.

noreactive fibers were also found in the hypothalamus in the area of hert neurons, but 5-HT cell bodies were not found in this hypothalamic area. Conversely, both hcrt immunoreactive greenlabeled cell bodies and fibers were found in the lateral hypothalamic area, but only fibers were found in the DRN. Green-labeled hcrt immunoreactive fibers were found near a majority of redlabeled 5-HT immunoreactive cell bodies in the DRN (Fig. $8 C, D)$. As many as $15 \mathrm{hcrt}$ boutons were found around single 5-HT cells and their primary dendrites. In addition, hert fibers were found surrounding other neurons in the DRN that showed no 5-HT-related immunoreactivity.

In another set of experiments, we examined hort and GABA in the DRN. Recent immunocytochemical studies have shown that GABA and 5-HT cells represent separate and distinct populations of neurons in the DRN (Stamp and Semba, 1995). We found green-labeled hcrt-immunoreactive boutons adjacent to redlabeled GABA/GABA-transporter immunoreactive cells (Fig.
$\mathrm{A}_{1}$

2

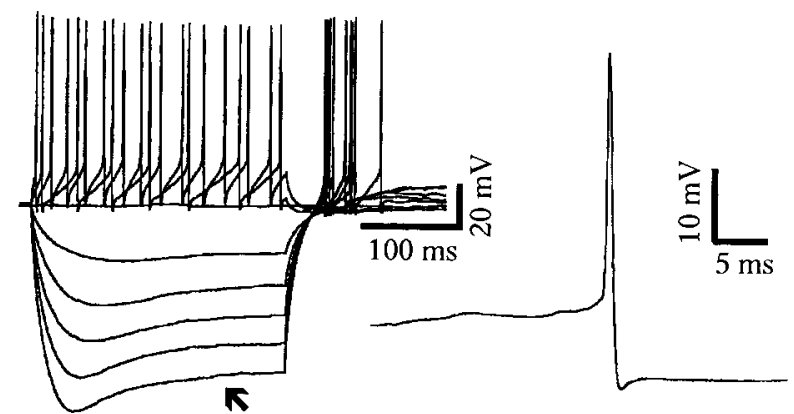

B 1

hert2 $(1 \mu \mathrm{M})$

2

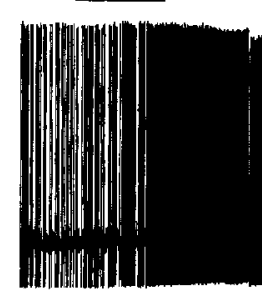

Figure 7. Hcrt-induced increase in spiking of non-5-HT cells in the DRN. A1, Whole-cell current-clamp recording showing the response of a non-5-HT neuron to depolarizing and hyperpolarizing current steps (step size, $-0.05 \mathrm{nA}$; maximum step, $-0.25 \mathrm{nA}$ ). Note the depolarizing sag in the hyperpolarizing electrotonic responses (arrow). A2, Also note the short spike duration of this cell $(0.45 \mathrm{msec}$ at half amplitude). B1, A continuous recording from this cell shows an increase in the firing rate induced by $1 \mu \mathrm{M}$ hcrt2. B2, The rate record shows that this non-5-HT neuron responds to hcrt 2 with a $120 \%$ increase in the firing rate.

$8 B$ ). Controls included using only a single primary antiserum or only a single secondary antiserum. Absorption controls were done in which the antigen (hcrt, GABA, or 5-HT) was immersed with the primary antiserum overnight before adding to the histological section, and this blocked staining. With single immunostaining, only a single color was found, appropriate to the secondary conjugate used, indicating that the fluorescent filters were selective for a single fluorescent molecule. It remains to be determined whether the hcrt-immunoreactive boutons form conventional synapses or release peptide from nonsynaptic sites.

\section{DISCUSSION}

The present results indicate that low concentrations of hcrt1 and hort2 have a direct excitatory effect on 5-HT neurons, predominantly by inducing a TTX-insensitive, $\mathrm{Na}^{+}$-dependent inward current. After blocking potassium channels with intracellular cesium, the reversal potential of this current was determined to be near $-18 \mathrm{mV}$, typical of a mixed $\mathrm{Na}^{+} / \mathrm{K}^{+}$nonselective cation current. In addition, at higher concentrations, horts had an indirect inhibitory action on 5-HT cells by inducing a TTX-sensitive increase in IPSC frequency in 5-HT cells, suggesting that GABAergic interneurons in the DRN had been excited. Direct evidence for the latter was obtained by means of whole-cell recordings from IR/DIC visualized small $(-10 \mu \mathrm{M})$, putative GABA interneurons in the DRN. Thus, unexpectedly, in addition to their direct excitatory effects, hcrts were found to have indirect inhibitory effects on 5-HT DRN neurons.

Another novel finding was that hort2 was as potent as hert1 in 

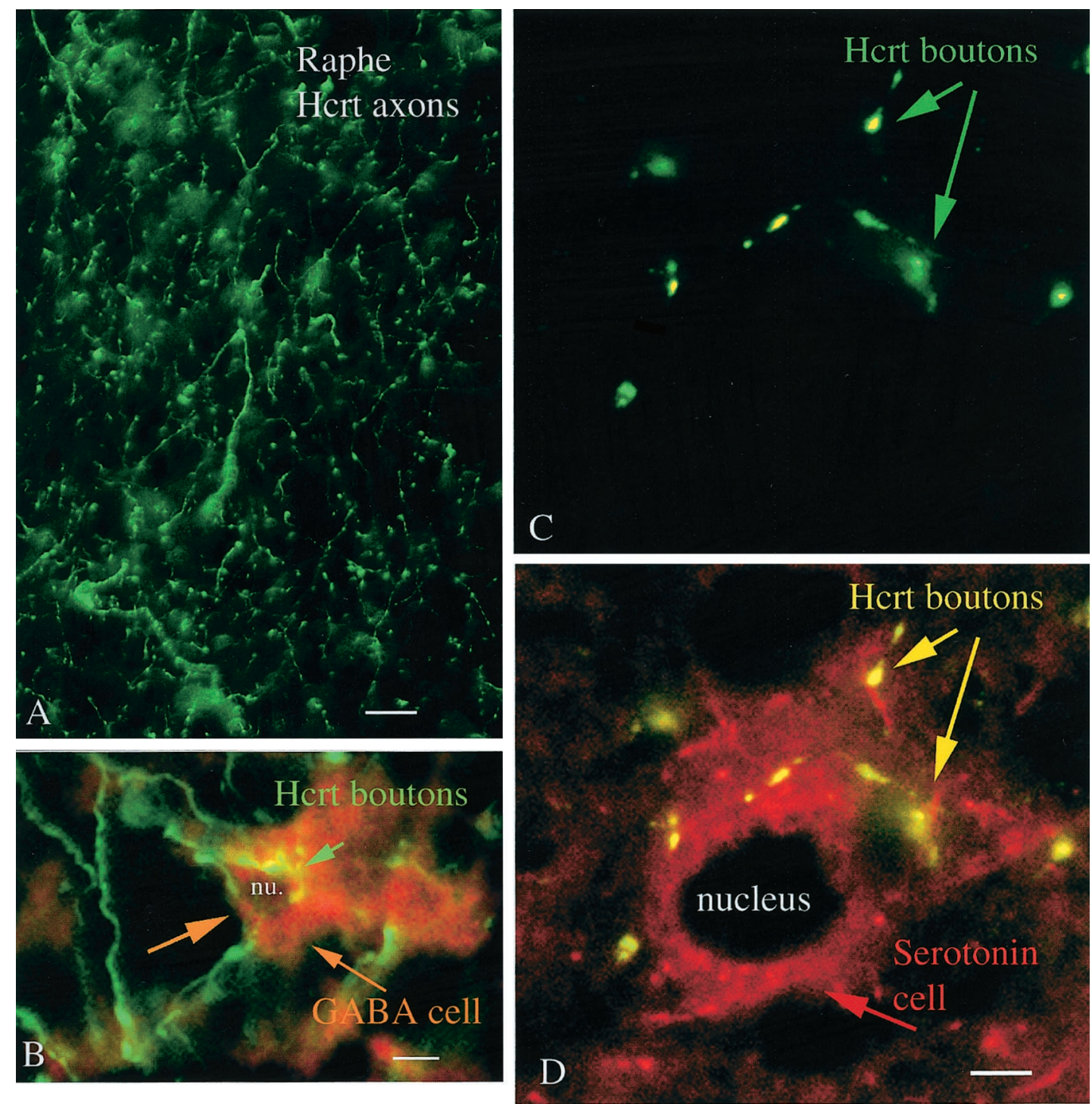

Figure 8. Hcrt axons in proximity of 5-HT- and GABA-immunoreactive neurons in the DRN. $A$, Hcrt immunoreactive axons show a high level of innervation of the DRN. Scale bar, $10 \mu \mathrm{m}$. B, In double-labeled immunofluorescence experiments, Alexa-488-labeled green hcrt immunoreactive fibers were found surrounding reddish Alexa-594-labeled cell bodies immunoreactive for GABA/GABA transporter. $n u$., Nucleus. Scale bar, $5 \mu$ m. $C$, Hcrt immunoreactive axons are labeled green with FITC. $D$, These greenish-yellow axons are found to surround a reddish cell body immunoreactive for the 5-HT transporter. Scale bar, $2.5 \mu \mathrm{m}$.

the DRN. This is possibly explained by the activation of hcrtR2, which shows similar responses to hort1 and hert2 (Sakurai et al., 1998). However, a recent in situ hybridization study found that both hortR1 mRNA and hortR2 mRNA were expressed in the DRN (Marcus et al., 2001), suggesting that both receptors probably underlie the actions of the horts in the DRN. It is interesting to note that both the locus ceruleus and the DRN are considered to play a role in the sleep-wake cycle as REM-off areas; they both receive a dense hcrt input. However, in contrast to 5-HT neurons of the DRN, noradrenergic neurons of the locus ceruleus have a substantially smaller excitatory response to hert2 than to hert1 (Bourgin et al., 2000; van den Pol et al., 2002), consistent with in situ hybridization showing only hortR1 in the locus ceruleus (Greco and Shiromani, 2001).

\section{Ionic mechanisms of the hcrt-induced inward currents}

The inward current induced by horts in 5-HT neurons was not blocked by the fast $\mathrm{Na}^{+}$channel blocker TTX or a $\mathrm{Ca}^{2+}$-free/ high- $\mathrm{Mg}^{2+}$ solution, indicating a direct postsynaptic action. Replacement of extracellular $\mathrm{NaCl}$ by equimolar choline chloride or Tris hydrochloride reduced the hcrt-induced current by $>80 \%$, showing it to be predominantly a TTX-insensitive $\mathrm{Na}^{+}$dependent inward current. A similar reduction of the hcrtinduced inward current in low $\mathrm{Na}^{+}$solution was found in the neurons of the dorsal motor nucleus of the vagus (Hwang et al., 2001). Brown et al. (2001) suggested that block of a $\mathrm{K}^{+}$leak conductance is involved in the excitatory effect of hort1 on 5-HT neurons in the DRN. However, in the present study we found that the reversal potential of the hcrt-induced inward current in normal ACSF is far from $E_{\mathrm{K}}$. In low-sodium ACSF, some cells showed an apparent reversal potential near $-100 \mathrm{mV}$, which was suggestive of a decrease in $\mathrm{K}^{+}$conductance $\left(\mathrm{G}_{\mathrm{k}}\right)$. However, because we could not reduce $\mathrm{Na}^{+}$below $20 \%$ of normal ACSF (Shen and North, 1992), it was not possible to study $G_{k}$ in isolation from the cationic current. Given these limitations, it is 
difficult to assess the magnitude of a $G_{k}$ component of the hortinduced inward current. However, in the experiments with $\mathrm{CsCl}$ electrodes to block inwardly rectifying and other $\mathrm{K}^{+}$channels, the reversal potential of the large cationic current could be examined in relative isolation. Under these conditions, we found an increased conductance and a reversal potential of $-18 \mathrm{mV}$, which is characteristic of nonselective cation channels (i.e., intermediate between the $E_{\mathrm{Na}}{ }^{+}$and $E_{\mathrm{K}}{ }^{+}$).

It is interesting to note that other Gq-coupled peptide receptors have also been reported to activate $\mathrm{Na}^{+}$-dependent inward currents. In medullary motoneurons, the hypothalamic peptides vasopressin and oxytocin have been shown to induce a TTXresistant, $\mathrm{Na}^{+}$-dependent current (Raggenbass et al., 1991; Raggenbass and Dreifuss, 1992). In single-channel recordings from dopaminergic neurons of the substantia nigra, it has been demonstrated that neurotensin-induced $\mathrm{Na}^{+}$-dependent inward currents are mediated by nonselective cation channels (Chien et al., 1996). However, in tuberomammillary neurons, it has been suggested that the excitatory effects of hcrt are mediated primarily through activation of the electrogenic $\mathrm{Na}^{+} / \mathrm{Ca}^{2+}$ exchanger (Eriksson et al., 2001). However, it should be noted that operation of the forward electrogenic $\mathrm{Na}^{+} / \mathrm{Ca}^{2+}$ exchanger is highly dependent on internal $\mathrm{Ca}^{2+}$ (Ehara et al., 1989). In contrast, nonselective cation channels are not affected by changes in intracellular $\mathrm{Ca}^{2+}$, because loading cells with the high-affinity $\mathrm{Ca}^{2+}$ chelator BAPTA does not reduce inward currents (Farkas et al., 1996). In the present study, intracellular loading of 5-HT cells with the BAPTA chelator did not reduce the hort-induced inward current, pointing to mediation of hcrt-induced inward currents by nonselective cation channels rather than the $\mathrm{Na}^{+} / \mathrm{Ca}^{2+}$ exchanger.

\section{Network effects of hcrt in the DRN}

The present study shows that horts have an indirect inhibitory influence on 5-HT neurons, as shown by an increase in the frequency of spontaneous IPSCs. The slice preparation probably underestimates this influence, because many DRN interneurons are likely to have been disconnected from 5-HT cells because they lie outside the confines of the slice. Using whole-cell recording from IR/DIC-visualized small $(\sim 10 \mu \mathrm{m})$ cells in the DRN, we find that hcrts excite a subset of putative GABAergic neurons, paralleling the increase in IPSCs. Consistent with these results, immunocytochemistry showed the presence of hort fibers and boutons near both 5-HT and GABA neurons in the DRN. Previous studies have shown that horts evoke a substantial increase in synaptic activity in neurons recorded from the hypothalamus (de Lecea et al., 1998; van den Pol et al., 1998, 2001) and spinal cord (Grudt et al., 2002). The data from the present study show that hcrts are more potent in producing direct excitatory effects on 5-HT neurons than in activating GABAergic inhibitory inputs. This suggests that these indirect inhibitory effects may have a negative feedback function, which would come into play primarily during higher levels of hort activity.

\section{Functional implications}

Hcrts have been implicated in feeding, energy homeostasis, neuroendocrine functions, and cardiovascular control (Sakurai et al., 1998; van den Pol. et al., 1998; Samson et al., 1999). Perhaps most importantly, recent observations implicate this newly described neurotransmitter system in the regulation of the sleep-wake cycle (Kilduff and Peyron, 2000). Loss of hcrt neurons in the hypothalamus appears to be the most common cause of narcolepsy in humans, a disease characterized by excessive daytime sleepiness and slow arousal, unusual REM sleep patterns, cataplexy, and hypnogogic hallucinations (Peyron et al., 2000; Thannickal et al., 2000). Mice with a deletion of the hcrt gene (Chemelli et al., 1999) exhibit a phenotype strikingly similar to that seen in human patients with narcolepsy. Canines with a mutation of hcrtR2 display the complete narcolepsy syndrome (Lin et al., 1999). In contrast, a selective hcrtR1 antagonist reduces food intake in rats without inducing sedation (Rodgers et al., 2001). Together, these results imply a relatively greater role for hortR2 than hortR1 in modulating the sleep-wake cycle. The present results strongly implicate hcrtR2 receptors in the action of hcrts on 5-HT neurons (see above). Thus, the DRN/5-HT system needs to be considered among the candidate neuronal systems through which horts orchestrate the sleep-wake cycle.

It has been hypothesized that activation of 5-HT neurons contributes to the function of ascending arousal systems projecting to the forebrain (O'Hearn and Molliver, 1984; McQuade and Sharp, 1995, 1997; Portas et al., 1998). Within the brainstem, serotonergic inputs to REM-sleep active areas in the pedunculopontine tegmental and laterodorsal tegmental nucleus (Honda and Semba, 1994; Vertes and Kocsis, 1994) would tend to suppress REM sleep (Thakkar et al., 1998; Monti and Monti, 2000; Portas et al., 2000). Consistent with this model, in vitro data have shown that $5-\mathrm{HT}$ and $5-\mathrm{HT}_{1 \mathrm{~A}}$ agonists inhibit neurons in those regions (Luebke et al., 1992; Leonard and Llinas, 1994). Furthermore, microinjections of 5-HT into the laterodorsal tegmental nucleus in behaving (unanesthetized) cats and rats have been shown to produce a dose-dependent suppression of REM sleep (Sanford et al., 1994; Horner et al., 1997). In addition, there is direct evidence that suppression of 5-HT neuronal activity in the DRN increases REM sleep (Portas et al., 1996). Thus, direct activation of 5-HT neurons by herts could promote wakefulness or suppress sleep states through these and other brainstem and forebrain projections.

GABAergic inputs to 5-HT cells in the DRN have also been implicated in the regulation of the sleep-wake cycle. Iontophoretic application of the $\mathrm{GABA}_{\mathrm{A}}$ antagonist bicuculline into the DRN of cats has been shown to reverse the slowing of 5-HT cells that occurs during slow-wave but not REM sleep (Levine and Jacobs, 1992). Similarly, studies in the unanesthetized rat show that iontophoretic application of bicuculline into the DRN reverses the slowing of 5-HT neurons in slow-wave and REM sleep and further increases activity during waking (Gervasoni et al., 2000). The latter study suggests that an increase in GABAergic inhibition, derived in part from the pontine ventral periaqueductal gray matter, is responsible for the decrease in activity of DRN 5-HT cells during REM sleep. In the present study, we have found that high concentrations of herts can have an indirect inhibitory effect on 5-HT cells by exciting GABAergic interneurons in the DRN area. It remains to be determined how herts interact with other transmitters in regulating the GABAergic inputs to the 5-HT cells. Nevertheless, the present results show that the influence of hcrts in the DRN is more complex than simply the direct excitation of 5-HT neurons.

\section{REFERENCES}

Aghajanian GK, Lakoski JM (1984) Hyperpolarization of serotonergic neurons by serotonin and LSD: studies in brain slices showing increased $\mathrm{K}^{+}$conductance. Brain Res 305:181-185.

Aghajanian GK, Vandermaelen CP (1982) Intracellular identification of central noradrenergic and serotonergic neurons by a new double labeling procedure. J Neurosci 2:1786-1792.

Baraban JM, Wang RY, Aghajanian G (1978) Reserpine suppression of 
dorsal raphe neuronal firing: mediation by adrenergic system. Eur J Pharmacol 52:27-36.

Blakely RD, Berson HE, Fremeau Jr RT, Caron MG, Peek MM, Prince HK, Bradley CC (1991) Cloning and expression of a functional serotonin transporter from rat brain. Nature 354:66-70.

Bourgin P, Huitron-Resendiz S, Spier AD, Fabre V, Morte B, Criado JR, Sutcliffe JG, Henriksen SJ, de Lecea L (2000) Hypocretin-1 modulates rapid eye movement sleep through activation of locus ceruleus neurons. J Neurosci 20:7760-7765.

Brown RE, Sergeeva O, Eriksson KS, Haas HL (2001) Orexin A excites serotonergic neurons in the dorsal raphe nucleus of the rat. Neuropharmacology 40:457-459.

Burlhis TM, Aghajanian GK (1987) Pacemaker potentials of serotonergic dorsal raphe neurons: contribution of a low-threshold $\mathrm{Ca}^{2+}$ conductance. Synapse 1:582-588.

Cespuglio R, Faradji H, Gomez ME, Jouvet M (1981) Single unit recordings in the nuclei raphe dorsalis and magnus during the sleepwaking cycle of semi-chronic prepared cats. Neurosci Lett 24:133-138.

Chemelli RM, Willie JT, Sinton CM, Elmquist JK, Scammell T, Lee C, Richardson JA, Williams SC, Xiong Y, Kisanuki Y, Fitch TE, Nakazato M, Hammer RE, Saper CB, Yanagisawa M (1999) Narcolepsy in orexin knockout mice: molecular genetics of sleep regulation. Cell 98:437-451.

Chien PY, Farkas RH, Nakajima S, Nakajima Y (1996) Single-channel properties of the nonselective cation conductance induced by neurotensin in dopaminergic neurons. Proc Natl Acad Sci USA 93:14917-14921.

Dahlstrom A, Fuxe K (1964) Evidence for the existence of monoamine containing neurons in the central nervous system. I. Demonstration of monoamines in the cell bodies of brain stem neurons. Acta Physiol Scand 62:1-55.

Decavel C, van den Pol AN (1990) GABA: a dominant neurotransmitter in the hypothalamus. J Comp Neurol 302:1019-1037.

de Lecea L, Kilduff TS, Peyron C, Gao X, Foye PE, Danielson PE, Fukuhara C, Battenberg EL, Gautvik VT, Bartlett II FS, Frankel WN, van den Pol AN, Bloom FE, Gautvik KM, Sutcliffe JG (1998) The hypocretins: hypothalamus-specific peptides with neuroexcitatory activity. Proc Natl Acad Sci USA 95:322-327.

Ehara T, Matsuoka S, Noma A (1989) Measurement of reversal potential of $\mathrm{Na}^{+}-\mathrm{Ca}^{2+}$ exchange current in single guinea-pig ventricular cells. J Physiol (Lond) 410:227-249.

Eriksson KS, Sergeeva O, Brown RE, Haas HL (2001) Orexin/hypocretin excites the histaminergic neurons of the tuberomammillary nucleus. J Neurosci 21:9273-9279.

Farkas RH, Chien PY, Nakajima S, Nakajima Y (1996) Properties of a slow nonselective cation conductance modulated by neurotensin and other neurotransmitters in midbrain dopaminergic neurons. J Neurophysiol 76:1968-1981.

Formenti A, De Simoni A, Arrigoni E, Martina M (2001) Changes in extracellular $\mathrm{Ca}^{2+}$ can affect the pattern of discharge in rat thalamic neurons. J Physiol (Lond) 535:33-45.

Gallager DW, Aghajanian GK (1976) Effect of antipsychotic drugs on the firing of dorsal raphe cells. I. Role of adrenergic system. Eur J Pharmacol 39:341-355.

Gervasoni D, Peyron C, Rampon C, Barbagli B, Chouvet G, Urbain N, Fort P, Luppi PH (2000) Role and origin of the GABAergic innervation of dorsal raphe serotonergic neurons. J Neurosci 20:4217-4225.

Goodman LA (1954) Kolmogorov-Smirnov tests for psychological research. Psychol Bull 51:160-168.

Greco MA, Shiromani PJ (2001) Hypocretin receptor protein and mRNA expression in the dorsolateral pons of rats. Brain Res Mol Brain Res 88:176-182.

Grudt TJ, van den Pol AN, Perl ER (2002) Hypocretin-2 (orexin-B) modulation of superficial dorsal horn activity in rat. J Physiol (Lond) 538:517-525.

Honda T, Semba K (1994) Serotonergic synaptic input to cholinergic neurons in the rat mesopontine tegmentum. Brain Res 647:299-306.

Horner RL, Sanford LD, Pack AI, Morrison AR (1997) Activation of a distinct arousal state immediately after spontaneous awakening from sleep. Brain Res 778:127-134.

Houdouin F, Cespuglio R, Gharib A, Sarda N, Jouvet M (1991) Detection of the release of 5-hydroxyindole compounds in the hypothalamus and the $\mathrm{n}$. raphe dorsalis throughout the sleep-waking cycle and during stressful situations in the rat: a polygraphic and voltammetric approach. Exp Brain Res 85:153-162.

Hwang LL, Chen CT, Dun NJ (2001) Mechanisms of orexin-induced depolarizations in rat dorsal motor nucleus of vagus neurones in vitro. J Physiol (Lond) 537:511-520.

Iwamoto T, Watano T, Shigekawa M (1996) A novel isothiourea derivative selectively inhibits the reverse mode of $\mathrm{Na}^{+} / \mathrm{Ca}^{2+}$ exchange in cells expressing NCX1. J Biol Chem 271:22391-22397.

Jolas T, Aghajanian GK (1996) Neurotensin excitation of serotonergic neurons in the dorsal raphe nucleus of the rat in vitro. Eur J Neurosci $8: 153-161$.
Jouvet M (1999) Sleep and serotonin: an unfinished story. Neuropsychopharmacology 21 [Suppl 2]:24S-27S.

Kilduff TS, Peyron C (2000) The hypocretin/orexin ligand-receptor system: implications for sleep and sleep disorders. Trends Neurosci 23:359-365.

Leonard CS, Llinas R (1994) Serotonergic and cholinergic inhibition of mesopontine cholinergic neurons controlling REM sleep: an in vitro electrophysiological study. Neuroscience 59:309-330.

Levine ES, Jacobs BL (1992) Neurochemical afferents controlling the activity of serotonergic neurons in the dorsal raphe nucleus: microiontophoretic studies in the awake cat. J Neurosci 12:4037-4044.

Lin L, Faraco J, Li R, Kadotani H, Rogers W, Lin X, Qiu X, de Jong PJ, Nishino S, Mignot E (1999) The sleep disorder canine narcolepsy is caused by a mutation in the hypocretin (orexin) receptor 2 gene. Cell 98:365-376.

Liu RJ, van den Pol AN, Aghajanian GK (2001) Hypocretins (orexins) regulate 5-HT neurons in the dorsal raphe nucleus (DRN) by both direct and indirect actions. Soc Neurosci Abstr 27:701.5.

Liu RJ, Ding YQ, Aghajanian GK (2002) Neurokinins activate local glutamatergic inputs to serotonergic neurons of the dorsal raphe nucleus. Neuropsychopharmacology 27:329-340.

Luebke JI, Greene RW, Semba K, Kamondi A, McCarley RW, Reiner PB (1992) Serotonin hyperpolarizes cholinergic low-threshold burst neurons in the rat laterodorsal tegmental nucleus in vitro. Proc Natl Acad Sci USA 89:743-747.

Lydic R, McCarley RW, Hobson JA (1987) Serotonin neurons and sleep. II. Time course of dorsal raphe discharge, $\mathrm{PGO}$ waves, and behavioral states. Arch Ital Biol 126:1-28.

Marcus JN, Aschkenasi CJ, Lee CE, Chemelli RM, Saper CB, Yanagisawa M, Elmquist JK (2001) Differential expression of orexin receptors 1 and 2 in the rat brain. J Comp Neurol 435:6-25.

McGinty DJ, Harper RM (1976) Dorsal raphe neurons: depression of firing during sleep in cats. Brain Res 101:569-575.

McIntire SL, Reimer RJ, Schuske K, Edwards RH, Jorgensen EM (1997) Identification and characterization of the vesicular GABA transporter. Nature 389:870-876.

McQuade R, Sharp T (1995) Release of cerebral 5-hydroxytryptamine evoked by electrical stimulation of the dorsal and median raphe nuclei: effect of a neurotoxic amphetamine. Neuroscience 68:1079-1088.

McQuade R, Sharp T (1997) Functional mapping of dorsal and median raphe 5-hydroxytryptamine pathways in forebrain of the rat using microdialysis. J Neurochem 69:791-796.

Monti JM, Monti D (2000) Role of dorsal raphe nucleus serotonin $5-\mathrm{HT}_{1 \mathrm{~A}}$ receptor in the regulation of REM sleep. Life Sci 66:1999-2012.

O'Hearn E, Molliver ME (1984) Organization of raphe-cortical projections in rat: a quantitative retrograde study. Brain Res Bull 13:709-726.

Parsons JE, Wallis RA, Panizzon KL, Wasterlain CG (1992) Low sodium injury in the hippocampal slice is mediated through NMDA receptors. Brain Res 595:141-144.

Peyron C, Tighe DK, van den Pol AN, de Lecea L, Heller HC, Sutcliffe JG, Kilduff TS (1998) Neurons containing hypocretin (orexin) project to multiple neuronal systems. J Neurosci 18:9996-10015.

Peyron C, Faraco J, Rogers W, Ripley B, Overeem S, Charnay Y, Nevsimalova S, Aldrich M, Reynolds D, Albin R, Li R, Hungs M, Pedrazzoli M, Padigaru M, Kucherlapati M, Fan J, Maki R, Lammers GJ, Bouras C, Kucherlapati R, et al (2000) A mutation in a case of early onset narcolepsy and a generalized absence of hypocretin peptides in human narcoleptic brains. Nat Med 6:991-997.

Portas CM, McCarley RW (1994) Behavioral state-related changes of extracellular serotonin concentration in the dorsal raphe nucleus: a microdialysis study in the freely moving cat. Brain Res 648:306-312.

Portas CM, Thakkar M, Rainnie D, McCarley RW (1996) Microdialysis perfusion of 8-hydroxy-2-(di- $n$-propylamino)tetralin (8-OH-DPAT) in the dorsal raphe nucleus decreases serotonin release and increases rapid eye movement sleep in the freely moving cat. J Neurosci $16: 2820-2828$

Portas CM, Bjorvatn B, Fagerland S, Gronli J, Mundal V, Sorensen E, Ursin R (1998) On-line detection of extracellular levels of serotonin in dorsal raphe nucleus and frontal cortex over the sleep/wake cycle in the freely moving rat. Neuroscience 83:807-814.

Portas CM, Bjorvatn B, Ursin R (2000) Serotonin and the sleep/wake cycle: special emphasis on microdialysis studies. Prog Neurobiol 60:13-35

Puizillout JJ, Gaudin-Chazal G, Daszuta A, Seyfritz N, Ternaux JP (1979) Release of endogenous serotonin from "encephale isole" cats. II. Correlations with raphe neuronal activity and sleep and wakefulness. J Physiol (Paris) 75:531-537.

Raggenbass M, Dreifuss JJ (1992) Mechanism of action of oxytocin in rat vagal neurones: induction of a sustained sodium-dependent current. J Physiol (Lond) 457:131-142.

Raggenbass M, Goumaz M, Sermasi E, Tribollet E, Dreifuss JJ (1991) Vasopressin generates a persistent voltage-dependent sodium current in a mammalian motoneuron. J Neurosci 11:1609-1616.

Rodgers RJ, Halford JC, Nunes de Souza RL, Canto de Souza AL, Piper DC, Arch JR, Upton N, Porter RA, Johns A, Blundell JE (2001) 
SB-334867, a selective orexin-1 receptor antagonist, enhances behavioural satiety and blocks the hyperphagic effect of orexin-A in rats. Eur J Neurosci 13:1444-1452.

Sakurai T, Amemiya A, Ishii M, Matsuzaki I, Chemelli RM, Tanaka H, Williams SC, Richardson JA, Kozlowski GP, Wilson S, Arch JR, Buckingham RE, Haynes AC, Carr SA, Annan RS, McNulty DE, Liu WS, Terrett JA, Elshourbagy NA, Bergsma DJ, et al (1998) Orexins and orexin receptors: a family of hypothalamic neuropeptides and $\mathrm{G}$ protein-coupled receptors that regulate feeding behavior. Cell 92:573-585.

Samson WK, Gosnell B, Chang JK, Resch ZT, Murphy TC (1999) Cardiovascular regulatory actions of the hypocretins in brain. Brain Res 831:248-253.

Sanford LD, Ross RJ, Seggos AE, Morrison AR, Ball WA, Mann GL (1994) Central administration of two 5-HT receptor agonists: effect on REM sleep initiation and PGO waves. Pharmacol Biochem Behav 49:93-100.

Shen KZ, North RA (1992) Muscarine increases cation conductance and decreases potassium conductance in rat locus coeruleus neurones. J Physiol (Lond) 455:471-485. arsid538899

Sobolevsky AI, Khodorov BI (1999) Blockade of NMDA channels in acutely isolated rat hippocampal neurons by the $\mathrm{Na}^{+} / \mathrm{Ca}^{2+}$ exchange inhibitor KB-R7943. Neuropharmacology 38:1235-1242.

Stamp JA, Semba K (1995) Extent of colocalization of serotonin and GABA in the neurons of the rat raphe nuclei. Brain Res 677:39-49.

Stuart GJ, Dodt HU, Sakmann B (1993) Patch-clamp recordings from the soma and dendrites of neurons in brain slices using infrared video microscopy. Pflügers Arch 423:511-518. arsid538899

Thakkar MM, Strecker RE, McCarley RW (1998) Behavioral state con- trol through differential serotonergic inhibition in the mesopontine cholinergic nuclei: a simultaneous unit recording and microdialysis study. J Neurosci 18:5490-5497.

Thannickal TC, Moore RY, Nienhuis R, Ramanathan L, Gulyani S, Aldrich M, Cornford M, Siegel JM (2000) Reduced number of hypocretin neurons in human narcolepsy. Neuron 27:469-474.

Trulson ME, Jacobs BL (1979) Raphe unit activity in freely moving cats: correlation with level of behavioral arousal. Brain Res 163:135-150.

van den Pol AN, Gao XB, Obrietan K, Kilduff TS, Belousov AB (1998) Presynaptic and postsynaptic actions and modulation of neuroendocrine neurons by a new hypothalamic peptide, hypocretin/orexin. J Neurosci 18:7962-7971.

van den Pol AN, Patrylo PR, Ghosh PK, Gao XB (2001) Lateral hypothalamus: early developmental expression and response to hypocretin (orexin). J Comp Neurol 433:349-363.

van den Pol AN, Ghosh PK, Liu RJ, Li Y, Aghajanian GK, Gao XB (2002) Hypocretin (orexin) enhances neuron activity and cell synchrony in developing mouse GFP-expressing locus coeruleus. J Physiol (Lond) 541:169-185.

Vandermaelen CP, Aghajanian GK (1983) Electrophysiological and pharmacological characterization of serotonergic dorsal raphe neurons recorded extracellularly and intracellularly in rat brain slices. Brain Res 289:109-119.

Vertes RP, Kocsis B (1994) Projections of the dorsal raphe nucleus to the brainstem: PHA-L analysis in the rat. J Comp Neurol 340:11-26.

Watano T, Kimura J, Morita T, Nakanishi H (1996) A novel antagonist, no. 7943, of the $\mathrm{Na}^{+} / \mathrm{Ca}^{2+}$ exchange current in guinea-pig cardiac ventricular cells. Br J Pharmacol 119:555-563. 